\title{
DERECHO Y POLÍTICAS AMBIENTALES EN LA REGIÓN DE MURCIA
} (pp. 2-21)

\section{DRET I POLÍTIQUES AMBIENTALS EN LA REGIÓ DE MÚRCIA (pp.} 22-40)

\author{
SANTIAGO M. ÁLVAREZ CARREÑO \\ Profesor titular de Derecho Administrativo / Professor titular de dret administratiu \\ Universidad de Murcia \\ EDUARDO SALAZAR ORTUÑO \\ Abogado / Advocat
}


Sumario: 1. Reflexiones introductorias. 2. El progresivo desarrollo de los instrumentos previstos en la Ley 4/2009, de 14 de mayo, de Protección Ambiental Integrada (LPAI). 2.1. El ralentizado proceso de desarrollo y aplicación de la Ley. 2.2. La necesaria reforma del sistema de licencias municipales. 2.3. La aprobación de ordenanzas locales que adaptan, parcialmente, el nuevo régimen de la licencia de actividad. 3. Otras manifestaciones de la política y legislación ambiental de la Administración regional en Murcia. 3.1. Fauna silvestre. 3.2 Acuicultura. 3.3. Espacios naturales protegidos. 3.4. Fiscalidad ambiental. 3.5. Acceso a la información ambiental. 3.6. Fomento. 3.7. Política forestal. 4. Ordenanzas municipales ambientales. 4.1 Ruidos y vibraciones. 4.2. Infraestructuras radioeléctricas. 4.3. Contaminación lumínica. 4.4 Agricultura tradicional. 5. Algunas reflexiones finales sobre el período objeto de crónica.

\section{Reflexiones introductorias}

El período que va desde finales de 2010 hasta mayo de 2011, objeto de esta crónica, ha estado marcado por la ausencia de normas auténticamente relevantes en materia de protección del medio ambiente. La reciente presentación en sociedad del anteproyecto de Ley de Conservación de la Naturaleza y Biodiversidad de la Región de Murcia en el marco de una Jornada sobre medio natural y desarrollo económico de la Región de Murcia, organizada por la Confederación de Empresarios (CROEM) y celebrada el pasado 4 de marzo, podría significar un paso adelante que, sin embargo, debe ser tomado con gran cautela por encontrarnos inmersos en período electoral, tan lleno de promesas de futuro como de incumplimientos posteriores...

Por otra parte, el proceso de desarrollo y aplicación de la Ley 4/2009, de 14 de mayo, de Protección Ambiental Integrada (en adelante, LPAI) viene marcado por la situación de crisis económica, y, en consecuencia, por la falta del esfuerzo financiero necesario para su cabal puesta en práctica.

En la presente crónica daremos cuenta de algunos tímidos avances del derecho y la política ambiental en el ámbito territorial de la Región de Murcia. En esta ocasión, se presta especial atención a la diferente y abundante normativa local, entre la que encontramos normas de indudable interés aun cuando muchas de ellas presenten una descuidada factura fruto de una deficiente técnica de producción normativa.

\section{El progresivo desarrollo de los instrumentos previstos en la Ley 4/2009, de 14 de mayo, de Protección Ambiental Integrada (LPAI)}

\subsection{El ralentizado proceso de desarrollo y aplicación de la Ley}


Los principales esfuerzos se vienen concentrando en la consolidación de la profunda reforma procedimental llevada a cabo por la LPAI, norma de cuyos contenidos hemos ido dando cumplida referencia en nuestras anteriores crónicas. Esta Ley, como se señaló, establece el régimen jurídico y los procedimientos integrados de intervención administrativa a los que deben sujetarse los planes, los programas, los proyectos y las actividades que pueden afectar al medio ambiente. En este sentido, en la anterior crónica consignamos tres pequeños avances en el proceso aplicativo de la Ley, que se resiente, sin duda, de la escasez de medios materiales y humanos dispuestos para su implementación y de la escasa voluntad política de lograr una profunda reforma de la gestión ambiental, agravada por la actual situación de crisis económica, que determina el pase a un segundo plano de las preocupaciones ambientales.

Para el presente período objeto de crónica se pueden señalar, sin embargo, algunos pasos en esta transformación del modo de actuación de la Administración regional en materia de medio ambiente. En primer lugar, mediante la Orden de 17 de marzo de 2011 de la Consejería de Agricultura y Agua se aprueba, en aplicación del artículo 130 de la LPAI, el Plan de Inspección Ambiental de la Actividad Industrial del año 2011. La LPAI dedica el capítulo I del título VIII al control y la disciplina ambiental. Su artículo 125 regula las actividades sujetas a vigilancia y control ambiental; el artículo 126 establece las competencias en la vigilancia e inspección ambiental, y, en fin, el artículo 127 define las clases de inspección ambiental.

De este modo, el objetivo básico del Plan de Inspección Ambiental consiste en comprobar el grado de cumplimiento de la normativa ambiental y de los requisitos impuestos en las autorizaciones ambientales autonómicas de las actividades e instalaciones potencialmente contaminantes de la Región de Murcia que se encuentren dentro del ámbito de aplicación de la LPAI, y en identificar las actividades no autorizadas.

\subsection{La necesaria reforma del sistema de licencias municipales ${ }^{1}$}

Antes de la entrada en vigor de la LPAI, el ámbito material de la licencia de actividad venía determinado por el artículo 214.b) del Decreto Legislativo 1/2005, de 10 de junio,

\footnotetext{
${ }^{1}$ Agradezco al Sr. Manuel GIL QUILES, jefe de la Asesoría Jurídica Ambiental de la Consejería de Agricultura y Agua de la CARM, su colaboración en la elaboración de esta crónica y, en concreto, su consentimiento para publicar estas reflexiones sobre la reforma del sistema de licencias municipales.
} 
que aprueba el texto refundido de la Ley del Suelo de la Región de Murcia (TRLSMur), según el cual la licencia de actividad "se exigirá para cualquier actividad mercantil o industrial que se pretenda desarrollar, tanto en el interior de edificaciones como en espacios libres. También se exigirá para cualquier modificación que se pretenda realizar de los usos existentes, así como para los usos de carácter provisional”.

El concepto proviene del artículo 22.1 del Reglamento de Servicios de las Corporaciones Locales -RSCL- (Decreto de 17 de junio de 1955), que sujetaba a licencia "la apertura de establecimientos industriales y mercantiles". Desde entonces ha recaído un enorme caudal de jurisprudencia, no siempre uniforme, que trata de analizar caso a caso lo que se entiende por "establecimiento industrial y mercantil". Esos criterios jurisprudenciales casuísticos se han seguido aprovechando por la legislación urbanística regional, por entender que la “actividad mercantil o industrial” de la norma urbanística equivale a "establecimiento industrial y mercantil” del Reglamento de Servicios.

El artículo 59.1 de la LPAI, Ley murciana 4/2009, afirma que "se exigirá licencia de actividad para la instalación, montaje, ejercicio o explotación, traslado o modificación sustancial de cualquier actividad mercantil o industrial que se pretenda desarrollar, ya sea de titularidad pública o privada, tanto en el interior de edificaciones como en espacios libres, tenga o no finalidad lucrativa”. El apartado se completa con unos supuestos de no sujeción a licencia de actividad.

Al operar de esta manera, la LPAI ha introducido importantes precisiones respecto del TRLSMur, pero no ha modificado los términos centrales que determinan el ámbito de sujeción a licencia (“actividad mercantil o industrial”), ni tampoco ha definido esos términos, con lo que sigue sin existir una definición legal de lo que se entiende por “actividad mercantil o industrial” a efectos de licencia de actividad. En consecuencia, también después de la LPAI habrá que recurrir a la interpretación casuística que vienen haciendo los tribunales de justicia, exactamente igual que ocurría antes de la entrada en vigor de la Ley.

De hecho, la mayor parte de las precisiones que aparecen en la nueva LPAI vienen a plasmar esos criterios de creación jurisprudencial, lo que resulta evidente en los supuestos de no sujeción, o en la irrelevancia de que la actividad "sea de titularidad pública o privada” o que “tenga o no finalidad lucrativa”. Quizá las únicas verdaderas 
innovaciones que produce la LPAI en el ámbito de sujeción a licencia sean las siguientes:

1) Al enumerar como actuaciones sujetas a licencia, entre otras, la "modificación sustancial” de las actividades mercantiles o industriales, está excluyendo de licencia las modificaciones no sustanciales, que estarían sujetas al régimen de comunicación previa (art. 65 de la LPAI).

2) Ya no se sujeta a licencia de actividad "la modificación que se pretenda realizar de los usos existentes”, salvo que el cambio de uso tenga por objeto iniciar precisamente una actividad mercantil o industrial. Fuera de este supuesto, el cambio de uso estará sujeto a licencia urbanística, y, si se lleva a cabo sin título habilitante, se incurrirá en infracción urbanística (art. 237.1.f del TRLSMur). Igual ocurre con "los usos de carácter provisional”, solo sujetos a licencia de actividad si constituyen actividad mercantil o industrial, estando en el resto de los casos sujetos a licencia urbanística (art. 221 del TRLSMur).

3) Las actividades de carácter mercantil o industrial promovidas por la Comunidad Autónoma de la Región de Murcia, los ayuntamientos y las entidades de derecho público dependientes de aquella o de estos están sujetas (art. 59.1.b. de la LPAI, a contrario) pero exentas (art. 59.3 de la LPAI), por lo que el control ambiental se encauza, cuando proceda, bien a través de la autorización ambiental autonómica, bien mediante informe de calificación ambiental emitido por la Administración promotora de la actividad, que se insertará en el procedimiento de aprobación o autorización del proyecto.

La enorme variedad de supuestos concretos en los cuales la exigencia de licencia de actividad puede ser dudosa exigiría un análisis caso por caso de la jurisprudencia recaída. Existen, además, otras razones para reservar un juicio definitivo sobre el alcance de las futuras reformas:

a) Los ayuntamientos son los operadores jurídicos principales a la hora de esclarecer el ámbito de la licencia de actividad, por tener la competencia ejecutiva en la materia.

Para el ejercicio de las competencias ejecutivas autonómicas, la determinación del ámbito de la licencia solo es relevante en el caso de que la actividad esté sujeta a alguna autorización sectorial autonómica o a 
evaluación de impacto ambiental, pues será entonces cuando el proyecto se someta a autorización ambiental única si además la actividad está sujeta a licencia de actividad (véase anexo I de la LPAI).

b) Muchos ayuntamientos tienen aprobadas ordenanzas locales de actividad que desarrollan o aclaran el ámbito de la licencia de actividad en su término municipal, e incluso esta aclaración se hace a veces de manera indirecta, a través de las ordenanzas fiscales reguladoras de la tasa correspondiente. Otros tienen ya una línea de interpretación práctica consolidada después de muchos años de aplicación del régimen de la licencia.

Pero, sobre todo, porque el concepto de actividad mercantil o industrial como determinante del ámbito de la licencia de actividad se ha visto profundamente afectado por la transposición de la Directiva 2006/123, del Parlamento Europeo y del Consejo, de 12 de diciembre, sobre servicios en el mercado interior (conocida como Directiva de Servicios o, simplemente, DS). El fundamento jurídico para la aprobación de un instrumento como este se encuentra en los artículos 47 (2) y 55 del Tratado de la Comunidad Europea (TCE).

El objetivo perseguido con esta Directiva responde a la necesidad de alcanzar un mercado único de servicios en la Unión Europea, para lo que el Parlamento Europeo y el Consejo han fijado un conjunto de medidas tendentes a la supresión de las barreras legales y administrativas que limitan el desarrollo de actividades de servicios entre Estados miembros, a fin de ampliar las posibilidades de elección de los destinatarios y, en consecuencia, mejorar la calidad de los servicios. Nace así una de las piezas fundamentales de la estrategia comunitaria de impulso económico y de consolidación de mercado (conocida como Estrategia de Lisboa).

De acuerdo con el artículo 1 de la DS, la finalidad de la norma es "facilitar el ejercicio de la libertad de establecimiento de los prestadores de servicios y la libre circulación de los servicios”, y, al mismo tiempo, mantener un nivel elevado de calidad en los servicios.

El principal objetivo de la Directiva de Servicios consiste, pues, en crear un marco jurídico general que suprima los obstáculos que se oponen a las libertades económicas de los prestadores de servicios y mejore la calidad de los servicios (considerando 1. ${ }^{\circ}$ de la DS). En este sentido, debe recordarse que el artículo 14.2 del TCE se refiere al 
mercado interior como un espacio sin fronteras interiores en que la "libre circulación de mercancías, personas, servicios y capitales estará garantizada”. En materia de servicios, estas libertades se concretan en los artículos 43 del TCE, que garantiza la libertad de establecimiento, y 49 del TCE, que establece la libertad de prestación de servicios. Todo ello para fomentar el crecimiento económico y la creación de empleo, objetivo que tiene como elemento clave para su consecución la competitividad. Una competitividad que, en la actualidad, se ve debilitada por el gran número de barreras en el mercado interior que impiden a los prestadores extender sus operaciones más allá de sus fronteras nacionales y beneficiarse plenamente del mercado interior (considerando $2 .^{\circ}$ de la DS).

Por ello, todos los Estados miembros de la Unión Europea están obligados a conciliar su normativa interna con las disposiciones de la Directiva europea. Pues bien, esta situación ha generado notables efectos tanto para el futuro como en relación con normas preexistentes, y ello por cuanto la DS no solo ha determinado que las nuevas regulaciones se ajustaran a sus disposiciones, sino que también ha obligado a los Estados miembros a efectuar una revisión de sus respectivas normativas sobre servicios aplicando los principios básicos internacionalmente aceptados para establecer una regulación eficiente y favorecedora de la competencia. En concreto, se trata de los siguientes principios:

- Principio de necesidad: implica que toda norma que introduzca restricciones a la competencia tiene que venir precedida de una definición de sus objetivos y de una clara justificación de la introducción de las restricciones (existencia de una relación de causalidad entre la restricción a la competencia y la consecución del objetivo).

- Principio de proporcionalidad (justificación de la restricción): pretende evitar que los instrumentos en los que se materializa la restricción supongan solo una mejora relativa o marginal en términos de bienestar social, pero que, al mismo tiempo, generen un grave daño a este debido a las importantes restricciones a la actividad económica que imponen.

- Principio de mínima distorsión (justificación de los instrumentos utilizados): implica que, entre los instrumentos posibles para alcanzar un objetivo determinado, se tiene que escoger aquel que suponga la mínima afectación negativa a la competencia. 
- Principio de eficacia: supone la capacidad de la norma de alcanzar los objetivos o efectos que se desean.

- Principio de transparencia: implica la existencia de transparencia y claridad en el marco normativo, en el proceso de elaboración de las normas y en su ejecución.

- Principio de predictibilidad o previsibilidad: comporta ofrecer a los operadores un marco estable y sólido, sin incertidumbres, que les proporcione seguridad jurídica.

La Directiva de Servicios fue incorporada parcialmente a nuestro derecho interno a través de la conocida como Ley Paraguas, esto es, la Ley 17/2009, de 23 de noviembre, sobre el libre acceso a las actividades de servicios y su ejercicio, que supone una auténtica revolución liberalizadora al reducir las trabas “injustificadas o desproporcionadas” al acceso y ejercicio de actividades — según declara expresamente su exposición de motivos-, lo que proporciona un entorno más favorable a la creación de empresas, y que establece como regla general la libre prestación de los servicios.

No obstante, la transposición de la citada Directiva en España se completa con la conocida como Ley Ómnibus, esto es, la Ley 25/2009, de 22 de diciembre, de modificación de diversas leyes para su adaptación a la Ley sobre el libre acceso a las actividades de servicios y su ejercicio, que adapta la normativa estatal de rango legal a los postulados de la Ley 17/2009.

En efecto, el artículo 5 de la Ley 17/2009, de 23 de noviembre, sobre el libre acceso a las actividades de servicios y su ejercicio, establece que:

"la normativa reguladora del acceso a una actividad de servicios o del ejercicio de la misma no podrá imponer a los prestadores un régimen de autorización, salvo excepcionalmente y siempre que concurran las siguientes condiciones, que habrán de motivarse suficientemente en la Ley que establezca dicho régimen:

No discriminación [...];

Necesidad: que el régimen de autorización esté justificado por una razón imperiosa de interés general, $\mathrm{y}$

Proporcionalidad: que dicho régimen sea el instrumento más adecuado para garantizar la consecución del objetivo que se persigue porque no existen otras medidas menos restrictivas que permitan obtener el mismo resultado, en particular 
cuando un control a posteriori se produjese demasiado tarde para ser realmente eficaz. Así, en ningún caso, el acceso a una actividad de servicios o su ejercicio se sujetarán a un régimen de autorización cuando sea suficiente una comunicación o una declaración responsable del prestador mediante la que se manifieste, en su caso, el cumplimiento de los requisitos exigidos y se facilite la información necesaria a la autoridad competente para el control de la actividad”.

Consiguientemente, el artículo 84.1.b de la Ley 7/1985, de 2 de abril, reguladora de las Bases del Régimen Local (LBRL), recibió nueva redacción por la Ley 25/2009, de 22 de diciembre, de modificación de diversas leyes para su adaptación a la Ley sobre el libre acceso a las actividades de servicios y su ejercicio, afirmando actualmente que "las Entidades locales podrán intervenir la actividad de los ciudadanos a través de los siguientes medios: [...] sometimiento a previa licencia y otros actos de control preventivo. No obstante, cuando se trate del acceso y ejercicio de actividades de servicios incluidas en el ámbito de aplicación de la Ley 17/2009, de 23 de noviembre, sobre el libre acceso a las actividades de servicios y su ejercicio, se estará a lo dispuesto en la misma”.

Las dos leyes estatales citadas (Ley 17/2009 —Paraguas - y Ley 25/2009 — Ómnibus-) no se refieren específicamente a la licencia de actividad, pero sí lo hace el Real Decreto 2009/2009, de 23 de diciembre, por el que se modifica el Reglamento de Servicios de las Corporaciones Locales, aprobado por Decreto de 17 de junio de 1955. Este real decreto modifica el artículo 22.1 del RSCL, que afirma ahora que "la apertura de establecimientos industriales y mercantiles podrá sujetarse a los medios de intervención municipal, en los términos previstos en la legislación básica en materia de régimen local y en la Ley 17/2009, de 23 de noviembre, sobre el libre acceso a las actividades de servicios y su ejercicio”. El precepto goza, al amparo del artículo 149.1.18 de la Constitución (CE), de carácter básico.

Es significativo recordar aquí la redacción original del artículo 22.1 del RSCL, según la cual “estará sujeta a licencia la apertura de establecimientos industriales y mercantiles”. La exposición de motivos del Real Decreto considera que semejante redacción no se ajustaba ya a la LBRL y que era preciso modificarla ("es necesario realizar una modificación de la redacción de los artículos 5 y 22.1 del Reglamento de servicios de las corporaciones locales, aprobado por Decreto de 17 de junio de 1955, exclusivamente con el fin de adecuar su contenido a lo previsto en la mencionada modificación de la 
Ley 7/1985, de 2 de abril, y sin menoscabo de las competencias normativas que corresponden a las comunidades autónomas y de la autonomía local”).

La Ley 2/2011, de 4 de marzo, de Economía Sostenible (LES) da un paso más para acotar los supuestos de las licencias de actividad, añadiendo a la LBRL en su artículo 41 dos nuevos artículos, el 84 bis y 84 ter, con la siguiente redacción:

Artículo 84 bis.

Sin perjuicio de lo dispuesto en el artículo anterior, con carácter general, el ejercicio de actividades no se someterá a la obtención de licencia u otro medio de control preventivo. No obstante, podrán someterse a licencia o control preventivo aquellas actividades que afecten a la protección del medio ambiente o del patrimonio histórico-artístico, la seguridad o la salud públicas, siempre que la decisión de sometimiento esté justificada y resulte proporcionada. En caso de existencia de licencias o autorizaciones concurrentes entre una entidad local y alguna otra Administración, la entidad local deberá motivar expresamente en la justificación de la necesidad de la autorización o licencia el interés general concreto que se pretende proteger y que éste no se encuentra ya cubierto mediante otra autorización ya existente.

Artículo 84 ter.

Cuando el ejercicio de actividades no precise autorización habilitante y previa, las Entidades locales deberán establecer y planificar los procedimientos de comunicación necesarios, así como los de verificación posterior del cumplimiento de los requisitos precisos para el ejercicio de la misma por los interesados previstos en la legislación sectorial.

En conclusión, resulta necesario adaptar tanto la LPAI de la Región de Murcia como las ordenanzas locales al nuevo texto de los artículos 84, 84 bis y 84 ter de la LBRL. En este sentido, en el caso de las actividades exentas, los ayuntamientos pueden ya, a través de sus ordenanzas, "sustituir la licencia de actividad que resulta exigible por una comunicación previa del inicio de la actividad” (art. 63.4 de la LPAI). Con el nuevo texto del artículo 84 de la LBRL, esta sustitución no es una mera posibilidad, sino que es obligatoria en todos aquellos casos en que no se aprecien y se justifiquen "razones imperiosas de interés general” para mantener su exigencia (art. 5 de la Ley 17/2009). En el caso de las actividades sometidas a informe de calificación ambiental, será preciso introducir cambios en la propia LPAI. 
La regulación de la licencia de actividad — en la que la potestad de ordenanza de los entes locales convive con una competencia normativa autonómica que puede ser más o menos amplia- representa un ámbito en el que cobra especial importancia la colaboración entre la Administración autonómica y la local, para la cual está prevista la creación de una comisión de coordinación medioambiental que puede jugar en este campo un destacado papel.

2.3. La aprobación de ordenanzas locales que adaptan, parcialmente, el nuevo régimen de la licencia de actividad

Diversos ayuntamientos de la Región de Murcia han aprobado ordenanzas locales en el sentido que marcan las recientes modificaciones de la legislación estatal señaladas. Así, el BORM núm. 46, de 25 de febrero de 2011, da cuenta de la aprobación definitiva de la Ordenanza municipal del Ayuntamiento de Cehegín sobre simplificación administrativa en materia de implantación de actividades, cuyo objetivo principal consiste en disminuir la carga burocrática que tradicionalmente han soportado las empresas para su implantación en el término municipal.

El BORM núm. 62, de 16 de marzo de 2011, publica la Ordenanza de La Unión reguladora de las autorizaciones ambientales no sujetas a calificación ambiental, que se considera un avance parcial en el camino tendente a lograr el objetivo final de simplificar los trámites y procedimientos exigidos para la implantación de empresas y actividades.

Por su parte, el municipio de Abarán aprueba la Ordenanza reguladora de autorizaciones ambientales exentas de calificación ambiental (BORM núm. 76, de 2 de abril de 2011). Su justificación se hace en términos similares a las anteriormente reseñadas. En el mismo sentido, el BORM núm. 80, de 7 de abril de 2011, da cuenta de la aprobación inicial de la Ordenanza de Lorca reguladora de la licencia de primera ocupación.

\section{Otras manifestaciones de la política y legislación ambiental de la Administración regional en Murcia}

3.1. Fauna silvestre 
Dentro de las medidas de conservación de la fauna silvestre y de preservación de la biodiversidad regional, cabe mencionar el Decreto 90/2010, de 7 de mayo, por el que se crea la Red de Muladares para las Aves Rapaces Necrófagas, gestionada por la CARM, cuyo objeto, en el marco del Real Decreto 664/2007, de 25 de mayo, por el que se regula la alimentación de aves rapaces necrófagas con subproductos animales no destinados a consumo humano, es asegurar la alimentación de aves necrófagas con subproductos cárnicos no destinados al consumo humano. Los muladares de la Red se situarán en aquellos municipios donde se asienten colonias reproductoras y áreas de campeo de las rapaces necrófagas quebrantahuesos (Gypaetus barbatus), buitre leonado (Gyps fulvus) y alimoche (Neophron percnopterus).

\subsection{Acuicultura}

La Orden de 28 de mayo, de la Consejería de Agricultura y Agua, regula el Libro de Explotación Acuícola de la Región de Murcia, en el que se reflejarán los datos administrativos, técnicos, sanitarios y medioambientales de las instalaciones acuícolas que desarrollen su actividad productiva en la Región de Murcia, con lo que se da cumplimiento a las previsiones contenidas en la Directiva 2006/88/CE del Consejo, de 24 de octubre de 2006, relativa a los requisitos zoosanitarios de los animales y de los productos de la acuicultura, y a la prevención y el control de determinadas enfermedades de los animales acuáticos; en el Real Decreto 1614/2008, de 3 de octubre, y en la Ley 2/2007, de 12 de marzo, de Pesca Marítima y Acuicultura de la Región de Murcia.

Entre los datos ambientales que deben reflejarse, se incluyen los datos relativos a la fecha de resolución de la correspondiente declaración de impacto ambiental, a las actualizaciones con los diferentes seguimientos ambientales anuales de la actividad de la empresa y a las correspondientes auditorías trianuales realizadas por una entidad de control ambiental (ECA). Se harán constar asimismo la empresa u organismo que efectúa el seguimiento o auditoría, y la fecha en la que se ha entregado la preceptiva documentación ambiental al órgano administrativo competente.

\subsection{Espacios naturales protegidos}


En materia de espacios protegidos, además del Decreto 274/2010, de 1 de octubre, por el que se aprueba el Plan de Gestión y Conservación de la ZEPA de Isla Grosa - ya reseñado en la crónica anterior-, cabe señalar el Decreto 299/2010, de 26 de noviembre, del Plan de Gestión y Conservación de la ZEPA de Almenara, Moreras y Cabo Cope.

Además, Murcia ha aportado dos nuevas zonas húmedas para su inclusión en la lista de la Convenio de Ramsar, relativa, como se sabe, a humedales de importancia internacional, especialmente como hábitats de aves acuáticas: las Lagunas de Campotéjar y las de Las Moreras (Resolución de 25 de enero de 2011, de la Dirección General del Medio Natural y Política Forestal, por la que se publica el Acuerdo de Consejo de Ministros de 7 de enero de 2011, BOE núm. 30, de 4 de febrero de 2011).

\subsection{Fiscalidad ambiental}

En el ámbito de la fiscalidad ambiental, resultan reseñables las modificaciones efectuadas por la Ley 3/2010, de 27 diciembre, de modificación de la regulación de algunos de los tributos propios de la Comunidad Autónoma de la Región de Murcia. Por una parte, en su capítulo primero modifica la Ley 3/2002, de 20 de mayo, de Tarifa del Canon de Saneamiento para establecer que el rendimiento del Canon de Saneamiento se destina a la financiación de los gastos correspondientes a las infraestructuras públicas de saneamiento y depuración. Por otra parte, esta misma Ley, en su capítulo tercero “Impuestos medioambientales”-, modifica la Ley 9/2005, de 29 de diciembre, de Medidas Tributarias en materia de Tributos Cedidos y Tributos Propios, año 2006, en algunos aspectos de la regulación del Impuesto sobre Residuos, precisando el alcance del hecho imponible al excluir del concepto de residuo los procedentes de la minería que pasan a constituir un supuesto de no sujeción-, y, con el fin de reforzar la seguridad jurídica y las garantías de los contribuyentes, desarrollando el procedimiento y las técnicas de medición del volumen y peso de los residuos depositados en aquellos casos en los que procede la aplicación del método de estimación indirecta de la base imponible.

Por su parte, la Orden de 24 de enero de 2011, de la Consejería de Economía y Hacienda (BORM núm. 43, de 22 de febrero), por la que se publican las tarifas de las 
tasas y precios públicos aplicables en el 2011, regula las tasas en materia de medio ambiente y conservación de la naturaleza (grupo 2).

Sin embargo, lo más significativo en el ámbito de la normativa sobre fiscalidad ambiental es constatar el incumplimiento de la previsión contenida en la disposición adicional tercera de la LPAI, que establecía el mandato al Consejo de Gobierno de elaborar y aprobar un texto refundido de las disposiciones legales vigentes en materia de impuestos ambientales en el plazo de un año a partir de la entrada en vigor de la Ley (1 de enero de 2010).

\subsection{Acceso a la información ambiental}

La información sobre las decisiones y los procedimientos de la Dirección General de Planificación, Evaluación y Control Ambiental de la CARM ha alcanzado un mayor grado de transparencia y accesibilidad gracias a la Plataforma Digital Ambiental (http://www.difusionpeca.es/). Todavía con poco contenido, se pretende que constituya una plataforma informativa y de discusión sobre la política de calidad ambiental de la CARM.

En este sentido, la página referenciada contiene un enlace a un foro sobre la LPAI. De momento, está restringido a las entidades de control ambiental (ECA), los órganos autonómicos y los técnicos municipales, que son los intervinientes más frecuentes. Pero se espera que pronto se abra a todo el mundo. El foro lo modera un técnico de la propia Dirección General, pero sus análisis carecen de valor oficial, es decir, no constituyen la “interpretación auténtica”, de modo que sus respuestas carecen de eficacia jurídica. Aun así, permite dar seguridad jurídica y aclarar ambigüedades o dudas, cosa que es muy conveniente sobre todo para los ayuntamientos. Al entrar en el foro se advierte del valor no vinculante de la información suministrada.

En relación con los recursos electrónicos de contenido ambiental de la Región de Murcia, también cabe señalar el sitio web http://www.murcianatural.carm.es, con un rico contenido en información sobre la política y legislación ambiental de la Región de Murcia. De modo más específico, en lo que respecta al acceso público a los recursos de información en materia de medio ambiente, la Dirección General de Patrimonio Natural y Biodiversidad ha estado trabajando en un sistema de información geográfica y ambiental (SIGA) sobre cartografía digital, sistema que es muy útil para identificar los 
límites de los espacios protegidos, los montes, las zonas de hábitats y, en general, las zonas de sensibilidad ambiental. Por ello, los proyectistas y consultores deben tener en cuenta esta información en la elaboración de sus planes y proyectos (sitio web: http://www.murcianatural.carm.es/geocatalogo/\#).

\subsection{Fomento}

La Orden de 1 de febrero de 2011, de la Consejería de Agricultura y Agua (BORM de 12 de febrero de 2011), convocó la cuarta edición de los Premios de Desarrollo Sostenible de la Región de Murcia. Estos premios en materia de medio ambiente se vienen convocando desde el año 2002 y sus bases se han adaptado a los nuevos objetivos y criterios que ha introducido, en el ámbito del fomento del medio ambiente y de la lucha contra el cambio climático, la LPAI. Las modalidades previstas son las siguientes: premio de desarrollo sostenible, premio a la iniciativa frente al cambio climático, premio a la responsabilidad social corporativa en materia ambiental, premio a la educación ambiental y, por último, mención especial para reconocer la trayectoria en este ámbito de ciudadanos, empresas y otras organizaciones.

\subsection{Política forestal}

El Consejo de Gobierno de la CARM, en su reunión del 25 de marzo de 2001, aprobó el Plan de Protección Civil de Emergencia por Incendios Forestales en la Región de Murcia (Plan Infomur), para la prevención y lucha contra los incendios forestales durante la temporada 2011-2012.

El Plan fija los protocolos de actuación de los efectivos que participan en los trabajos de vigilancia, detección y extinción de los incendios, y el dispositivo de medios humanos y materiales para que la acción sea coordinada, todo ello con el fin de proteger a las personas, los bienes y el medio ambiente ante el riesgo de incendios forestales.

La prevención de incendios y su extinción son los ejes principales del Plan Infomur, para los que se cuenta con el Consorcio de Extinción de Incendios y Salvamento de la Región de Murcia y las brigadas forestales de defensa contraincendios, de intervención rápida, helitransportadas y de pronto auxilio, además de los voluntarios de Protección Civil. 
Asimismo, el Plan cuenta con tres helicópteros, de los que dos están de forma permanente en Alcantarilla y La Pila (Abarán), para afrontar las situaciones de emergencia, mientras que el tercero, ubicado en la pedanía lorquina de Zarcilla de Ramos, interviene en el período de peligro alto.

Además, se identifica el grado de riesgo de cada época del año en función de los parámetros marcados por la vulnerabilidad del territorio y la probabilidad de que se registren incendios, parámetros que pueden disminuir o agravar la situación de riesgo. En este sentido, la época de riesgo más elevado de incendios forestales es la comprendida entre el 1 de junio y el 30 de septiembre; la época de peligro medio, del 1 de abril al 31 de mayo, más el mes de octubre, mientras que el período de menor peligro abarca del 1 de noviembre al 31 de marzo.

\section{Ordenanzas municipales ambientales ${ }^{2}$}

\subsection{Ruidos y vibraciones}

El BORM de 9 de marzo de 2011 publica la Ordenanza de 10 de septiembre de 2009, del Ayuntamiento de La Unión, sobre protección del medio ambiente contra la emisión de ruidos y vibraciones.

La Ordenanza queda estructurada en nueve títulos. El título I contiene las normas generales (arts. 1-4); el título II introduce diversas definiciones (art. 5) y las normas sobre medición y valoración de ruidos (art. 6), así como las exigencias de homologación de los aparatos de medición (art. 7); el título III (arts. 8-11) regula los niveles de perturbación por ruidos; el título IV (art. 12) establece las condiciones acústicas de las edificaciones; el título V (arts. 13-19) regula las emisiones de ruidos procedentes de vehículos a motor; el título VI (arts. 20-40) contempla los ruidos procedentes de discotecas, bares con música, superficies comerciales y otras actividades, así como los procedentes de trabajos en la vía pública y de edificación, de actividades perturbadoras del descanso ajeno en el interior de las viviendas y, en fin, de sistemas de aviso acústico; el título VII regula la contaminación procedente de vibraciones (arts. 41 y 42) y las zonas de especial protección ambiental (arts. 43-49); el título VIII, titulado "Régimen jurídico", regula las actuaciones de inspección de los funcionarios

\footnotetext{
${ }^{2}$ La referencia completa a las ordenanzas ambientales de los municipios de la Región de Murcia está en el sitio web http://www.ciss.es/Ordenanzasmunicipales/index.html.
} 
municipales (arts. 50-56), y, por último, el título IX regula las infracciones y sanciones. La Ordenanza se completa con cuatro disposiciones transitorias, una disposición final —entrada en vigor- - y ocho anexos.

Esta amplia normativa adolece de diversas deficiencias que ponen de manifiesto una defectuosa técnica normativa y, más allá, un descuido impropio de una administración pública. Así, el transcurso de más de año y medio desde su aprobación hasta su publicación provoca que la Ordenanza adolezca de falta de adecuación a la legislación ambiental aprobada en el ínterin por la Administración de la CARM, señaladamente la Ley 4/2009, de 14 de mayo, de Protección Ambiental Integrada. Más allá, los fallos de numeración de los diversos títulos (hay dos títulos VI y dos VII) y los de redacción (por ejemplo, el artículo 14.1: “Se prohíbe forzar las marchas de los vehículos a motor produciendo ruidos molestos como aceleraciones, forzar el motor en pendientes, etc.”) ponen de manifiesto las deficiencias apuntadas.

\subsection{Infraestructuras radioeléctricas}

El BORM de 4 de marzo de 2011 publica la Ordenanza de 10 de septiembre de 2009, del Ayuntamiento de La Unión, reguladora de la instalación y el funcionamiento de infraestructuras radioeléctricas.

La justificación de esta norma municipal se encuentra en el gran desarrollo e implantación de las nuevas tecnologías de la comunicación, en concreto, de la telefonía móvil, cuya consecuencia es la proliferación de las instalaciones necesarias para el funcionamiento de estos medios de comunicación, infraestructuras que tienen un fuerte impacto sobre el paisaje urbano y natural y, más allá, sobre la calidad de vida de los ciudadanos. Por todo ello, la Ordenanza regula las condiciones aplicables a la localización, la instalación y el desarrollo de las infraestructuras radioeléctricas de comunicación.

Sin duda, uno de los aspectos de mayor preocupación para los ciudadanos respecto a este tipo de instalaciones es el relativo a la protección frente a los posibles efectos nocivos para la salud de las personas que puedan derivarse de la exposición a campos electromagnéticos (CEM). Esta ordenanza municipal establece una serie de cautelas en este sentido, tanto mediante la reglamentación de las condiciones urbanísticas, de 
protección ambiental y de seguridad que tendrán que cumplir este tipo de instalaciones, como mediante el sometimiento a licencia de la actividad inherente a ellas.

La Ordenanza queda estructurada en siete capítulos. El primero establece el objeto y su ámbito de aplicación (arts. 1 y 2), en concreto, regula las condiciones urbanísticas y medioambientales a las que deben someterse la ubicación, la instalación y el funcionamiento de estas infraestructuras en el municipio “a fin de que su implantación se realice con todas las garantías urbanísticas, medioambientales y de seguridad y salubridad para los ciudadanos y se produzca la menor ocupación y el mínimo impacto visual y medioambiental en el entorno” (art. 1); el capítulo II (arts. 3-7) contiene las reglas sobre planificación y desarrollo, en concreto, exige la aprobación de un plan de implantación como condición imprescindible para que el municipio otorgue las licencias pertinentes (art. 6); el capítulo III (arts. 8 y 9) regula las limitaciones de la instalación de estas infraestructuras y las condiciones de protección ambiental y de seguridad —con carácter general, las instalaciones radioeléctricas de telecomunicaciones deberán "utilizar la solución constructiva disponible en el mercado que, con las menores dimensiones, reduzca al máximo el impacto visual y ambiental”, y deberán "resultar compatibles con el entorno e integrarse arquitectónicamente de forma adecuada” (art. 9. 1)—; el capítulo IV (arts. 10-13) establece el régimen jurídico de las licencias; el capítulo V (arts. 14-17) fija las reglas de conservación y mantenimiento de las instalaciones; el capítulo VI introduce el régimen de protección de la legalidad y sancionador de las infracciones en este ámbito, y el capítulo VII establece el régimen fiscal.

La Ordenanza contiene, asimismo, una disposición adicional que prevé la creación de un registro especial en el que se inscribirán todas las instalaciones radioeléctricas que hayan obtenido las correspondientes licencias municipales, y tres disposiciones transitorias sobre instalaciones existentes, solicitudes presentadas y adaptación a cambios tecnológicos. Una disposición final —entrada en vigor- y un anexo — que contiene las definiciones de algunos conceptos utilizados — completan su contenido. 


\subsection{Contaminación lumínica}

El BORM de 17 de marzo de 2011 publica la Ordenanza municipal de regulación del alumbrado exterior para la prevención de la contaminación lumínica y la protección del medio nocturno del Ayuntamiento de La Unión.

La Ordenanza recuerda, en su exposición de motivos, que la contaminación lumínica constituye un despilfarro de energía que produce graves perjuicios de tipo económico, afecta negativamente a la atmósfera, daña la biodiversidad, perturba a la ciudadanía, provoca inseguridad vial e impide la contemplación y el disfrute del patrimonio cultural y científico que es el cielo estrellado. De este modo, define la contaminación lumínica como "la emisión de flujo luminoso de fuentes artificiales nocturnas en intensidades, direcciones, rangos espectrales y/u horarios innecesarios para la realización de las actividades previstas en la zona donde estén instaladas las luces” (art. 1.1). Entre otros, persigue los siguientes objetivos: promover la eficiencia energética y el ahorro de energía, proteger el medio ambiente nocturno, eliminar molestias y perjuicios a la ciudadanía, aumentar la seguridad vial y permitir el disfrute y la observación del cielo nocturno (art. 2). El capítulo II (arts. 5-9) establece las características y el funcionamiento de las instalaciones de alumbrado exterior relativas a las luminarias (art. 5), el flujo luminoso (art. 6), la iluminación ornamental y publicitaria y el paisaje minero (art. 7), y los cañones de luz y láser (artículo 8: “Dado que el uso de cañones de luz convencional y láser dirigidos hacia el cielo representa una actitud contraria a los principios expresados en esta Ordenanza, quedan prohibidos en todo el término municipal de La Unión”); por último, el artículo 9 establece el horario a partir del cual se debe proceder a la reducción de la intensidad lumínica.

El capítulo III (arts. 10-16) regula la intervención del Ayuntamiento tanto en relación con el diseño de las instalaciones de alumbrado exterior de los nuevos proyectos como con el mantenimiento de las existentes y la sustitución de las preexistentes. En concreto, “el Ayuntamiento de La Unión sustituirá los alumbrados existentes por otros que se adecuen a la presente Ordenanza en el plazo máximo de 9 años” (art. 11.1). Por último, la Ordenanza contiene un último capítulo, el IV, relativo al régimen sancionador, que incluye la obligación del infractor de reparar la causa origen de la infracción (art. 19.3). 


\subsection{Agricultura tradicional}

El BORM de 23 de abril de 2010 publica la Ordenanza de 5 de febrero de 2010, del Ayuntamiento de Cieza, reguladora del régimen de uso y protección de las acequias y su huerta.

La Ordenanza constata que las actividades agrarias tradicionales se encuentran en nuestros días en una situación difícil como consecuencia de las transformaciones sociales y económicas, que se dirigen hacia tareas relacionadas con el sector industrial, el agroindustrial y el terciario. La presente norma local pretende regular y recoger usos y costumbres de Cieza - municipio con una reconocida actividad agrícola y usos agrarios del suelo-, tales como los riegos inmemoriales que se realizan desde las acequias de su huerta, que merecen ser protegidos para velar por la tradición rural, la cual, hasta la industrialización, caracterizó los usos y las costumbres de esta localidad.

El sustrato consuetudinario de esta regulación determina la fuerte presencia de los usuarios, de modo que “cualquier propuesta de modificación, derogación o suspensión que afecte a esta Ordenanza, requerirá audiencia previa de la Junta Central de Usuarios de la huerta de riego de las acequias mayores” (art. 2). En efecto, la Ordenanza pretende “positivar” un cuerpo consuetudinario de normas de la vega norte del río Segura para la mejor resolución de los frecuentes conflictos que surgen como consecuencia del ejercicio de la agricultura.

Así, la Ordenanza delimita las infraestructuras que son propiedad de la Comunidad de Regantes y establece los derechos de paso y servidumbre sobre las fincas colindantes cauces, quijeros, malecones, escorredores y cimbras- (art. 4). Regula los caminos de servicio (art. 5) y el derecho de acceso de la Comunidad a través de fincas ajenas (art. 6), así como las tuberías de transporte y elevación (art. 7) y las zonas de protección (art. 9). Incluye también un artículo sobre prohibición de vertidos que, de forma adicional a la legislación estatal y autonómica aplicable, puede suponer una vía de protección complementaria del agua de riego (art. 8).

En definitiva, se trata de una ordenanza local con origen en normas consuetudinarias que pretende salvar los restos de la agricultura tradicional en una sociedad que ha experimentado un fuerte proceso de urbanización e industrialización. 


\section{Algunas reflexiones finales sobre el período objeto de crónica}

La ausencia de normativa ambiental relevante para el período objeto de crónica, reflejo de una verdadera atonía de las políticas ambientales en la Región de Murcia, contrasta con los ambiciosos objetivos ambientales que el presidente regional anunció en su discurso de investidura para esta languideciente VII legislatura. El incumplimiento de buena parte del programa de gobierno en este ámbito deja pendientes actuaciones anunciadas, como la aprobación de un plan integral de protección del Mar Menor que debía contemplar un conjunto de medidas medioambientales relativas al paisaje, el fomento de la sostenibilidad del transporte, el uso de energías alternativas y la ampliación de las playas naturales, así como programas de recuperación de encañizadas y de uso sostenible de este emblemático espacio marino.

En el "debe” de la cuenta de resultados se debe consignar, igualmente, la anunciada configuración de una verdadera red de espacios naturales con especial valor ambiental que preserve las peculiaridades de la flora $\mathrm{y}$ la fauna $\mathrm{y}$ la singularidad de los ecosistemas regionales. Por último, ya nada se sabe de la denominada Ciudad del Medio Ambiente, que, según el presidente de la CARM, incluiría el Centro Regional de Interpretación de la Naturaleza, el Centro de Recursos Filogenéticos de Especies Silvestres de la Región de Murcia, la Escuela Regional de Caza y Pesca, el Centro de Lucha contra Incendios y el Centro de la Biodiversidad.

En un contexto económico de grave crisis, la apuesta por un reforzamiento de la protección del medio ambiente y la naturaleza en la Comunidad Autónoma de la Región de Murcia queda nuevamente postergada. Confiamos, como hasta ahora, en que las próximas crónicas puedan dar cuenta de avances más sustanciales de la política y legislación ambiental en esta comunidad autónoma. 
Sumari: 1. Reflexions introductòries. 2. El desplegament progressiu dels instruments que preveu la Llei 4/2009, de 14 de maig, de protecció ambiental integrada (LPAI). 2.1. L’alentit procés de desplegament i aplicació de la Llei 2.2. La reforma necessària del sistema de llicències municipals. 2.3. L'aprovació d'ordenances locals que adapten, parcialment, el nou règim de llicència d'activitat. 3. Altres manifestacions de la política i legislació ambiental de l'Administració regional a Múrcia. 3.1. Fauna silvestre. 3.2 Aqüicultura. 3.3. Espais naturals protegits. 3.4. Fiscalitat ambiental. 3.5. Accés a la informació ambiental. 3.6. Foment. 3.7. Política forestal. 4. Ordenances municipals ambientals. 4.1 Sorolls i vibracions. 4.2. Infraestructures radioelèctriques. 4.3. Contaminació lumínica. 4.4 Agricultura tradicional. 5. Algunes reflexions finals sobre el període objecte de la crònica.

\section{Reflexions introductòries}

El període que va des de finals de 2010 fins al maig de 2011, objecte d’aquesta crònica, ha estat marcat per l'absència de normes autènticament rellevants en matèria de protecció del medi ambient. La recent presentació en societat de l’Avantprojecte de llei de conservació de la naturalesa i biodiversitat de la Regió de Múrcia en el marc de la Jornada sobre Medi Natural i Desenvolupament econòmic de la Regió de Múrcia, organitzada per la Confederació d’Empresaris (CROEM) i realitzada el passat 4 de març de 2011, podria significar un pas endavant, que s’ha d’esmentar, però, amb gran cautela, ja que ens trobem immersos en període electoral, tant ple de promeses de futur com d’incompliments posteriors.

D’altra banda, el procés de desplegament i aplicació de la Llei 4/2009, de 14 de maig, de protecció ambiental integrada (en endavant, LPAI), està marcat per la situació de crisi econòmica $i$, en conseqüència, per la falta d'esforç financer necessari perquè es posi totalment en pràctica.

En aquesta crònica reflectirem alguns avenços tímids del dret i de la política ambiental en l’àmbit territorial de la Regió de Múrcia. En aquesta ocasió, posem esment en la normativa local diferent i abundant, entre la qual trobem normes d'indubtable interès, tot i que, moltes presenten una factura descurada fruit d'una tècnica deficient de producció normativa.

\section{El desplegament progressiu dels instruments que preveu la Llei 4/2009, de 14 de maig, de protecció ambiental integrada (LPAI)}

\subsection{L’alentit procés de desplegament i aplicació de la Llei}

Els principals esforços es concentren en la consolidació de la profunda reforma procedimental duta a terme per l'LPAI, norma del contingut de la qual hem parlat 
àmpliament en les cròniques anteriors. Aquesta llei, com hem assenyalat, estableix el règim jurídic i els procediments integrats d'intervenció administrativa en què s’han de basar els plans, els programes, els projectes i les activitats que poden afectar el medi ambient. En aquest sentit, en la crònica anterior hem consignat tres avenços petits en el procés aplicatiu de la llei, que es ressent, sens dubte, de l'escassetat de mitjans materials i humans disposats per implementar-la i de l'escassa voluntat política d'aconseguir una reforma profunda de la gestió ambiental, agreujada per l'actual situació de crisi econòmica, que determina el pas de les preocupacions ambientals cap a un segon pla.

En aquest període objecte de crònica es poden assenyalar, però, alguns passos en aquesta transformació de la manera d'actuar de l'Administració regional en matèria de medi ambient. En primer lloc, mitjançant l'Ordre de 17 de març de 2011, de la Conselleria d'Agricultura i Aigua, s’aprova, en aplicació de l'article 130 LPAI, el Pla d’Inspecció Ambiental de l'Activitat Industrial de 2011. L’LPAI dedica el capítol I del títol VIII al control i la disciplina ambiental. L’article 125 regula les activitats subjectes a vigilància i control ambiental, l'article 126 estableix les competències en la vigilància i en la inspecció ambiental i, finalment, l'article 127 defineix els tipus d’inspecció ambiental.

D’aquesta manera, l’objectiu bàsic del Pla d’Inspecció Ambiental consisteix a comprovar el grau de compliment de la normativa ambiental i dels requisits que imposen les autoritzacions ambientals autonòmiques de les activitats i de les instal-lacions potencialment contaminants de la Regió de Múrcia que es troben en l’àmbit d'aplicació de l’LPAI, i el descobriment de les que no s’han autoritzat.

\subsection{La reforma necessària del sistema de llicències municipals ${ }^{1}$}

Abans de l'entrada en vigor de l'LPAI, l'àmbit material de la llicència d'activitat estava determinat per l'article 214. b) del Decret legislatiu 1/2005, de 10 de juny, que aprova el Text refós de la llei del sòl de la Regió de Múrcia (TRLSMur), segons el qual la llicència d'activitat "se exigirá para cualquier actividad mercantil o industrial que se pretenda desarrollar, tanto en el interior de edificaciones como en espacios libres.

\footnotetext{
${ }^{1}$ Agraeixo al Sr. Manuel GIL QUILES, cap de l’Assessoria Jurídica Ambiental de la Conselleria d’Agricultura, Aigua de la CARM, la seva col·laboració en l'elaboració d’aquesta crònica i, en concret, el seu consentiment per publicar aquestes reflexions sobre la reforma de llicencies municipals.
} 
También se exigirá para cualquier modificación que se pretenda realizar de los usos existentes, así como para los usos de carácter provisional”.

El concepte prové de l'article 22.1 del Reglament de serveis de les corporacions locals —RSCL— (Decret de 17 de juny de 1955), que subjectava a llicència "la apertura de establecimientos industriales y mercantiles”. Des de llavors ha recaigut un cabal enorme de jurisprudència, no sempre uniforme, que tracta d'analitzar cas a cas el que s’entén per “establecimiento industrial y mercantil”. La legislació urbanística regional ha continuat aprofitant aquests criteris jurisprudencials casuístics, ja que entén que l'”actividad mercantil o industrial” de la norma urbanística equival a l'“establecimiento industrial y mercantil” del Reglament de serveis.

L’article 59.1 de l’LPAI, Llei murciana 4/2009, afirma que “se exigirá licencia de actividad para la instalación, montaje, ejercicio o explotación, traslado o modificación sustancial de cualquier actividad mercantil o industrial que se pretenda desarrollar, ya sea de titularidad pública o privada, tanto en el interior de edificaciones como en espacios libres, tenga o no finalidad lucrativa”. L'apartat es completa amb supòsits de no-subjecció a llicència d’activitat.

Com que opera d'aquesta manera, l'LPAI ha introduït precisions importants respecte del TRLSMur, però no ha modificat els termes centrals que determinen l'àmbit de subjecció a llicència (“actividad mercantil o industrial”), ni tampoc ha definit aquests termes, amb la qual cosa continua sense haver-hi definició legal del que s'entén per “actividad mercantil o industrial” a efectes de llicència d’activitat. En conseqüència, després de l’LPAI també caldrà recórrer a la interpretació casuística que en fan els Tribunals de Justícia, exactament igual com passava abans que la llei entrés en vigor.

De fet, la major part de les precisions que apareixen en la nova LPAI plasmen aquests criteris de creació jurisprudencial, fet que resulta evident en els supòsits de nosubjecció, o en la irrellevància que l'activitat "sea de titularidad pública o privada” o que "tenga o no finalidad lucrativa”. Potser les úniques veritables innovacions que produeix l’LPAI en l’àmbit de subjecció de la llicència són les següents:

1a) En enumerar com a actuacions subjectes a llicència, entre altres, la "modificació substancial” de les activitats mercantils o industrials, exclou de llicència les modificacions no substancials, que estarien subjectes al règim de comunicació prèvia (art. 65 LPAI). 
2a) Ja no se subjecta a llicència d'activitat “la modificación que se pretenda realizar de los usos existentes”, llevat que el canvi d'ús tingui per objecte iniciar precisament una activitat mercantil o industrial. Fora d'aquest supòsit, el canvi d'ús està subjecte a llicència urbanística, i, si es porta a terme sense títol habilitant, s’incorre en infracció urbanística (art. 237.1.f TRLSMur). Passa el mateix amb "els usos de caràcter provisional”, que només estan subjectes a llicència d'activitat si constitueixen una activitat mercantil o industrial, mentre que la resta de casos estan subjectes a llicència urbanística (art. 221 TRLSMur).

3a) Les activitats de caràcter mercantil o industrial promogudes per la Comunitat Autònoma de la Regió de Múrcia, els ajuntaments o les entitats de dret públic que en depenen, hi estan subjectes (art. 59.1.B. LPAI, a contrari) però exemptes (art. 59.3 LPAI), i es canalitza el control ambiental, si escau, ja sigui a través de l'autorització ambiental autonòmica, ja sigui mitjançant l'informe de qualificació ambiental emès per l’Administració promotora de l'activitat, que s'ha de publicar en el procediment d’aprovació o autorització del projecte.

L'enorme varietat de supòsits concrets en els quals l'exigència de llicència d'activitat pot ser dubtosa exigiria una anàlisi cas per cas de la jurisprudència que hi recau. A més, existeixen altres raons per reservar un judici definitiu sobre l'abast de les futures reformes:

a) Els ajuntaments són els operadors jurídics principals a l'hora d'aclarir l'àmbit de la llicència d’activitat, ja que tenen competència executiva en la matèria.

Per exercir competències executives autonòmiques, la determinació de l’àmbit de la llicència només és rellevant en el cas que l'activitat estigui subjecta a alguna autorització sectorial autonòmica o a avaluació d'impacte ambiental, ja que és llavors quan el projecte se sotmet a autorització ambiental única si, a més, l’activitat està subjecta a llicència d'activitat (vegeu l'annex I LPAI).

b) Molts ajuntaments han aprovat ordenances locals d'activitat que despleguen o aclareixen l'àmbit de la llicència d'activitat al seu terme municipal, i, fins i tot, aquest aclariment es fa a vegades de manera indirecta, a través de les ordenances fiscals reguladores de la taxa corresponent. Altres tenen ja una línia d’interpretació pràctica consolidada després de molts anys d’aplicar el règim de la llicència. 
Però, sobretot, perquè el concepte d'activitat mercantil o industrial com a determinant de l'àmbit de la llicència d'activitat s'ha vist profundament afectat per la transposició de la Directiva 2006/123, del Parlament europeu i del Consell, de 12 de desembre, sobre serveis en el mercat interior (coneguda com a directiva de serveis o, simplement, DS). El fonament jurídic per aprovar un instrument com aquest es troba en els articles 47 (2) i 55 del Tractat de la Comunitat Europea (TCE).

L'objectiu perseguit amb aquesta directiva respon a la necessitat d'assolir un mercat únic de serveis a la Unió Europea, per la qual cosa el Parlament europeu i el Consell han fixat un conjunt de mesures tendents a suprimir les barreres legals i administratives que limiten el desenvolupament d'activitats de serveis entre estats membres, que amplien les possibilitats d’elecció dels destinataris i milloren, amb tot això, la qualitat dels serveis. D’aquesta manera neix una de les peces fonamentals de l'estratègia comunitària d’impuls econòmic i de consolidació de mercat (coneguda com a Estratègia de Lisboa).

D'acord amb l'article $1 \mathrm{DS}$, la finalitat de la norma és "facilitar el ejercicio de la libertad de establecimiento de los prestadores de servicio y la libre circulación de los servicios” i, alhora, mantenir un nivell elevat de qualitat en els serveis.

El principal objectiu de la directiva de serveis consisteix, doncs, a crear un marc jurídic general que suprimeixi els obstacles que s'oposen a les llibertats econòmiques dels prestadors de serveis i millorar la qualitat dels serveis (considerant l'art.1 DS). En aquest sentit, cal recordar que l'article 14. 2 TCE es refereix a un mercat interior com un espai sense fronteres interiors en què la "libre circulación de mercancías, personas y servicios y capitales estarà garantizada”. En matèria de serveis, aquestes llibertats es concreten en l'article 43 TCE, que garanteix la llibertat per establir-se, i l'article 49 TCE, que estableix la llibertat de prestar serveis. Tot això per fomentar el creixement econòmic i la creació d’ocupació, un dels elements clau dels quals per aconseguir aquest objectiu de desenvolupament econòmic és la competitivitat. Una competitivitat que, actualment, es veu debilitada pel gran nombre de barreres al mercat interior que impedeixen estendre les operacions als prestadors més enllà de les fronteres nacionals i beneficiar-se plenament del mercat interior (considerant l'art. 2 DS).

D’aquesta manera, tots els estats membres de la Unió Europea queden vinculats a conciliar la seva normativa interna amb les disposicions de la directiva europea. Doncs bé, aquesta situació ha generat notables efectes tant per al futur com amb relació a 
normes preexistents, i això ja que, no només va determinar que les noves regulacions s'ajustessin al seu mandat, sinó que la directiva de serveis obligava els estats membres a revisar la normativa vigent sobre serveis i aplicar els principis bàsics internacionalment acceptats per establir una regulació eficient i afavoridora de la competència i, en concret, els següents:

- Principi de necessitat: implica que tota norma que introdueixi restriccions a la competència s’ha de precedir de la definició d’objectius i de la justificació clara de la introducció de les restriccions (existència d'una relació de causalitat entre la restricció a la competència i la consecució de l’objectiu).

- Principi de proporcionalitat (justificació de la restricció): pretén evitar que els instruments en què es materialitza la restricció suposin només una millora relativa o marginal en termes de benestar social però que, alhora, hi generin un greu dany a causa de les importants restriccions a l'activitat econòmica que imposen.

- Principi de mínima distorsió (justificació dels instruments utilitzats): implica que, entre els instruments possibles per aconseguir un objectiu determinat, s'ha d'escollir el que suposi la mínima afectació negativa a la competència.

- Principi d'eficàcia: suposa la capacitat de la norma d'assolir els objectius o efectes que es vulguin.

- Principi de transparència: implica l'existència de transparència i claredat en el marc normatiu, en el procés d'elaboració de les normes i en l'execució.

- Principi de predictibilitat o previsibilitat, que comporta oferir un marc estable i sòlid als operadors, sense incerteses, que els proporcioni seguretat jurídica.

La directiva de serveis es va incorporar parcialment al nostre dret intern a través de la coneguda llei paraigua, és a dir, la Llei 17/2009, de 23 de novembre, de lliure accés de les activitats de serveis i el seu exercici, que suposa una autèntica revolució liberalitzadora, ja que redueix les traves “injustificadas o desproporcionadas” de l’accés i de l'exercici d'activitats —segons declara expressament l'exposició de motius—, proporciona un entorn més favorable a la creació d'empreses i estableix com a regla general la lliure prestació dels serveis.

No obstant això, la transposició de l'esmentada directiva a Espanya es completa amb el dictat de la coneguda com a llei òmnibus, és a dir, la Llei 25/2009, de 22 de desembre, 
de modificació de diverses lleis per adaptar a la llei el lliure accés a les activitats de serveis i el seu exercici, que adapta la normativa estatal de rang legal als postulats de la Llei 17/2009.

En efecte, l'article 5 de la Llei 17/2009, de 23 de novembre, sobre el lliure accés a les activitats de serveis i el seu exercici, estableix que:

"la normativa reguladora del acceso a una actividad de servicios o del ejercicio de la misma no podrá imponer a los prestadores un régimen de autorización, salvo excepcionalmente y siempre que concurran las siguientes condiciones, que habrán de motivarse suficientemente en la Ley que establezca dicho régimen:

No discriminación (...);

Necesidad: que el régimen de autorización esté justificado por una razón imperiosa de interés general, $y$

Proporcionalidad: que dicho régimen sea el instrumento más adecuado para garantizar la consecución del objetivo que se persigue porque no existen otras medidas menos restrictivas que permitan obtener el mismo resultado, en particular cuando un control a posteriori se produjese demasiado tarde para ser realmente eficaz. Así, en ningún caso, el acceso a una actividad de servicios o su ejercicio se sujetarán a un régimen de autorización cuando sea suficiente una comunicación o una declaración responsable del prestador mediante la que se manifieste, en su caso, el cumplimiento de los requisitos exigidos y se facilite la información necesaria a la autoridad competente para el control de la actividad".

Consegüentment, l'article 84.1.b de la Llei 7/1985, de 2 d'abril, reguladora de les bases de règim local (LBRL), es va haver de redactar de nou, d'acord amb la Llei 25/2009, de 22 de desembre, de modificació de diverses lleis per adaptar-lo a la llei sobre el lliure accés a les activitats de serveis i el seu exercici, i actualment afirma que "las Entidades locales podrán intervenir la actividad de los ciudadanos a través de los siguientes medios: (...) sometimiento a previa licencia y otros actos de control preventivo. No obstante, cuando se trate del acceso y ejercicio de actividades de servicios incluidas en el ámbito de aplicación de la Ley 17/2009, de 23 de noviembre, sobre el libre acceso a las actividades de servicios y su ejercicio, se estará a lo dispuesto en la misma”.

Les dues lleis estatals que acabem d'esmentar (L. 17/2009 —llei paraigua - i L. 25/2009 —llei òmnibus-), no es refereixen específicament a la llicència d'activitat, cosa que sí que fa el Reial decret 2009/2009, de 23 de desembre, pel qual es modifica el 
Reglament de serveis de les corporacions locals, aprovat pel Decret de 17 de juny de 1955. Aquest reial decret modifica l'article 22.1 RSCL, que ara afirma que "la apertura de establecimientos industriales y mercantiles podrá sujetarse a los medios de intervención municipal, en los términos previstos en la legislación básica en materia de régimen local y en la Ley 17/2009, de 23 de noviembre, sobre el libre acceso a las actividades de servicios y su ejercicio”. El precepte té caràcter bàsic, a l'empara de l’article 149.1.18 de la Constitució (CE).

És significatiu recordar la redacció original de l'article 22.1 RSCL, segons la qual “estarà sujeta a licencia la apertura de estableciminetos industriales y mercantiles”. L’exposició de motius del reial decret considera que aquesta redacció no s’ajustava a l'LBRL i que calia modificar-la ("es necesario realizar una modificación de la redacción de los artículos 5 y 22. 1 del Reglamento de servicios de las corporaciones locales, aprobado por Decreto de 17 de junio de 1955, exclusivamente con el fin de adecuar su contenido a lo previsto en la mencionada modificación de la Ley 7/1985, de 2 de abril, y sin menoscabo de las competencias normativas que corresponden a las comunidades autónomas y de la autonomía local”).

La Llei 2/2011, de 4 de març, d'economia sostenible (LES), fa un pas més per acotar els supòsits de les llicències d'activitat, i afegeix dos nous articles, el 84.bis i 84.ter, a la LBRL en l'article 41, que s'han redactat d'aquesta manera:

”Artículo 84. bis.

Sin perjuicio de lo dispuesto en el artículo anterior, con carácter general, el ejercicio de actividades no se someterá a la obtención de licencia u otro medio de control preventivo. No obstante, podrán someterse a licencia o control preventivo aquellas actividades que afecten a la protección del medio ambiente o del patrimonio histórico-artístico, la seguridad o la salud públicas, siempre que la decisión de sometimiento esté justificada y resulte proporcionada. En caso de existencia de licencias o autorizaciones concurrentes entre una entidad local y alguna otra Administración, la entidad local deberá motivar expresamente en la justificación de la necesidad de la autorización o licencia el interés general concreto que se pretende proteger y que éste no se encuentra ya cubierto mediante otra autorización ya existente.”

“Artículo 84. ter. 
Cuando el ejercicio de actividades no precise autorización habilitante y previa, las Entidades locales deberán establecer y planificar los procedimientos de comunicación necesarios, así como los de verificación posterior del cumplimiento de los requisitos precisos para el ejercicio de la misma por los interesados previstos en la legislación sectorial.”

En conclusió, cal adaptar tant l’LPAI de la Regió de Múrcia com les ordenances locals al nou text dels articles 84, 84 bis i 84 ter de l'LBRL. En aquest sentit, en el cas de les activitats exemptes, els ajuntaments, a través de les ordenances, poden "sustituir la licencia de actividad que resulta exigible por una comunicación previa del inicio de la actividad” (art. 63.4 LPAI) . Amb el nou text de l'article 84 LBRL, aquesta substitució no és una mera possibilitat, sinó que és obligatòria en tots els casos en què no s’apreciïn ni es justifiquin "razones imperiosas de interés general" per mantenir la seva exigència (art. 5 de la Llei 17/2009). En el cas de les activitats sotmeses a informe de qualificació ambiental, cal introduir canvis en la mateixa LPAI.

La regulació de la llicència d'activitat —en la qual conviuen la potestat d’ordenança dels ens locals amb una competència normativa autonòmica que pot ser més o menys àmplia — representa un àmbit en el qual té especial importància la col·laboració entre l’Administració autonòmica i local, per a la qual està prevista la creació d’una comissió de coordinació mediambiental, que pot tenir en aquest camp un paper destacat.

2.3. L'aprovació d'ordenances locals que adapten, parcialment, el nou règim de la llicència d'activitat

Diversos ajuntaments de la Regió de Múrcia han aprovat ordenances locals en el sentit que marquen les recents modificacions de la legislació estatal que s’han assenyalat. D’aquesta manera, el BORM núm. 46, de 25 de febrer de 2011, dóna compte de l'aprovació definitiva de l’Ordenança municipal de l'Ajuntament de Cehegín de simplificació administrativa en matèria d'implantació d'activitats l'objectiu principal de la quals consisteix a disminuir la càrrega burocràtica que tradicionalment han suportat les empreses per implantar-se en el terme municipal.

El BORM núm. 62, de 16 de març de 2011, publica l’Ordenança de La Unión reguladora de les autoritzacions ambientals no subjectes a qualificació ambiental, que es 
considera un avanç parcial en el camí tendent a aconseguir l'objectiu final de simplificar els tràmits i procediments que s’exigeixen per implantar empreses i activitats.

Per la seva banda, el municipi d’Abarán aprova l’Ordenança reguladora d'autoritzacions ambientals exemptes de qualificació ambiental (BORM, núm. 76, de 2 d’abril de 2011). Es justifica en termes similars al que s’han indicat anteriorment. En el mateix sentit, el BORM núm. 80, de 7 d’abril de 2011, dóna compte de l'aprovació inicial de l’Ordenança de Lorca reguladora de la llicència de primera ocupació.

\section{Altres manifestacions de la política i legislació ambiental de l’Administració regional a Múrcia}

\subsection{Fauna silvestre}

Entre les mesures de conservació de la fauna silvestre, i per tal de preservar la biodiversitat regional, cal esmentar el Decret 90/2010, de 7 de maig, pel qual es crea la xarxa d'abocadors per a aus rapinyaires necròfagues gestionats per la CARM, la finalitat del qual, en el marc del Reial decret 664/2007, de 25 de maig, pel qual es regula l'alimentació d'aus rapaces necròfagues amb subproductes animals no destinats a consum humà, és assegurar l'alimentació de les aus necròfagues amb subproductes carnis no destinats al consum humà. Els abocadors de la xarxa s'han de situar en els municipis on s'assenten colònies reproductores i àrees d'esbarjo dels trencalossos (Gypaetus barbatus), voltors (Gyps fulvus) i aufranys (Neophron percnopterus).

\subsection{Aqüicultura}

L'Ordre de la Conselleria d'Agricultura i Aigua, de 28 de maig, regula el Llibre d’explotació aqüícola de la Regió de Múrcia, en el qual es reflecteixen les dades administratives, tècniques, sanitàries i mediambientals de les instal-lacions aqüícoles que duen a terme la seva activitat productiva a la Regió de Múrcia, d’acord amb les previsions que conté la Directiva 2006/88/CE del Consell, de 24 d'octubre de 2006, relativa als requisits zoosanitaris dels animals i dels productes de l'aqüicultura, i a la prevenció i el control de determinades malalties dels animals aquàtics; en el Reial decret 1614/2008, de 3 d’octubre, i en la Llei 2/2007, de 12 de març, de pesca marítima i aqüicultura de la Regió de Múrcia. 
Entre les dades ambientals que s'han de reflectir s'inclouen les dades relatives a la data de resolució de la corresponent declaració d'impacte ambiental, les actualitzacions amb els diferents seguiments ambientals anuals de l'activitat de l'empresa, així com de les corresponents auditories trianuals realitzades per una entitat de control ambiental (ECA). Així mateix, s’ha de fer constar l'empresa o l'organisme que efectua el seguiment o l'auditoria, així com la data en què s’ha lliurat la documentació ambiental perceptiva a l’òrgan administratiu competent.

\subsection{Espais naturals protegits}

En matèria d'espais protegits, a més del Decret 274/2010, d'1 d'octubre, pel qual s’aprova el Pla de Gestió i Conservació de la ZEPA d’illa Grosa, esmentat en la crònica anterior, el Decret 299/2010, de 26 de novembre, del Pla de Gestió i Conservació de la ZEPA d'Almenara, Moreras i del cap Cope.

A més, Múrcia ha aportat dues zones humides noves per incloure en la llista del Conveni de Ramsar, relatiu, com sabeu, a zones humides d'importància internacional especialment com a hàbitat d'aus aquàtiques: les llacunes de Campotejar i les de les Moreras (Resolució, de 25 gener 2011, de la Direcció General del Medi Natural i Política Forestal, per la qual es publica l'Acord de Consell de Ministres, de 7 de gener de 2011, BOE, núm. 30, de 4 de febrer de 2011).

\section{4. Fiscalitat ambiental}

En l'àmbit de la fiscalitat ambiental, resulten destacables les esmenes efectuades per la Llei 3/2010, de 27 desembre, de modificació de la regulació d’alguns tributs propis de la Comunitat Autònoma de la Regió de Múrcia. D’una banda, en el capítol primer, modifica la Llei 3/2002, de 20 de maig, de la tarifa del cànon de sanejament per establir que el rendiment del cànon de sanejament es destina a finançar les despeses corresponents a les infraestructures públiques de sanejament i depuració. D’altra banda, aquesta mateixa llei, en el capítol tercer — “Impostos mediambientals”_, modifica la Llei 9/2005, de 29 de desembre, de mesures tributàries en matèria de tributs cedits i tributs propis, any 2006, en alguns aspectes de la regulació de l'impost sobre residus, i precisa l'abast del fet imposable, ja que exclou del concepte de residu els procedents de la mineria que passen a constituir un supòsit de no subjecció i, així mateix, per tal de 
reforçar la seguretat jurídica i les garanties dels contribuents, es desplega el procediment i les tècniques de mesura del volum i pes dels residus dipositats en els casos en què és procedent aplicar el mètode d'estimació indirecta de la base imposable.

Per la seva banda, l'Ordre, de 24 de gener de 2011, de la Conselleria d'Economia i Hisenda (BORM, núm. 43, de 22 de febrer), per la qual es publiquen les tarifes de les taxes i preus públics aplicables el 2011, regula les taxes en matèria de medi ambient i conservació de la natura (grup 2).

No obstant això, el més significatiu en l'àmbit de la normativa sobre fiscalitat ambiental és constatar l’incompliment de la previsió que conté la disposició addicional tercera de l'LPAI, que establia el mandat al Consell de Govern per elaborar i aprovar el text refós de les disposicions legals vigents en matèria d'impostos ambientals, en el termini d'un any a partir de l'entrada en vigor de la llei (1de gener de 2010).

\subsection{Accés a la informació ambiental}

La informació sobre les decisions i els procediments de la Direcció General de Planificació, Avaluació i Control Ambiental de la CARM ha assolit un grau més gran de transparència i accessibilitat mitjançant la plataforma digital ambiental (http://www.difusionpeca.es/). Tot i que amb poc contingut, es pretén que constitueixi una plataforma informativa i de discussió sobre la política de qualitat ambiental de la CARM.

En aquest sentit, el lloc web esmentat conté l'enllaç al fòrum sobre l'LPAI. De moment, està restringit a les entitats de control ambiental (ECA), òrgans autonòmics i tècnics municipals, que són els intervinents més freqüents. Però s’espera que s’obri aviat a tot el món. El fòrum el modera un tècnic de la mateixa Direcció General però les seves anàlisis no tenen valor oficial, és a dir, no constitueixen la “interpretació autèntica”, de manera que les respostes no tenen eficàcia jurídica. Tot i això, permet donar seguretat jurídica i aclarir ambigüitats o dubtes, cosa que, sobretot per als ajuntaments, és molt convenient. El valor no vinculant de la informació subministrada s'adverteix quan s’entra al fòrum.

Amb relació als recursos electrònics de contingut ambiental de la Regió de Múrcia, convé deixar constància igualment del lloc web <http://www.murcianatural.carm.es>, amb un contingut ric en informació sobre la política i legislació ambiental de la Regió 
de Múrcia. De manera més específica, en matèria d’accés públic als recursos d’informació en matèria de medi ambient, la Direcció General de Patrimoni Natural i Biodiversitat ha estat treballant en el Sistema d’Informació Geogràfica i Ambiental — SIGA - sobre cartografia digital, que és molt important per identificar límits dels espais protegits, muntanyes, zones d’hàbitats i, en general, zones de sensibilitat ambiental. D’aquesta manera, els projectistes i els consultors han de tenir en compte aquesta informació en l'elaboració dels plans i projectes (lloc web: $<$ http://www.murcianatural.carm.es/geocatalogo/ \#>).

\subsection{Foment}

L'Ordre, d'1 de febrer de 2011, de la Conselleria d'Agricultura i Aigua (BORM, de 12 de febrer de 2011) ha convocat la quarta edició dels Premis de Desenvolupament Sostenible de la Regió de Múrcia. Aquests premis en matèria de medi ambient es convoquen des de 2002, i les bases s'han adaptat als nous objectius i criteris que introdueix, en matèria de foment del medi ambient i de lluita contra el canvi climàtic, l’LPAI. Les modalitats previstes són: premi de desenvolupament sostenible, premi a la iniciativa davant el canvi climàtic, premi a la responsabilitat social corporativa en matèria ambiental, premi a l'educació ambiental i, finalment, menció especial per reconèixer la trajectòria en aquest àmbit de ciutadans, empreses i altres organitzacions.

\subsection{Política forestal}

El Consell de Govern de la CARM, en la reunió del 25 de març de 2001, va aprovar el Pla de Protecció Civil d’Emergència per a Incendis Forestals a la Regió de Múrcia (Pla Infomur), per prevenir i lluitar contra els incendis forestals per a la temporada 20112012.

El pla fixa els protocols d'actuació dels efectius que participen en els treballs de vigilància, detecció i extinció dels incendis i el dispositiu de mitjans humans i materials, perquè l'acció sigui coordinada i amb la finalitat de protegir persones, béns i el medi ambient davant del risc d'incendis forestals.

La prevenció d'incendis i l'extinció són els eixos principals del Pla Infomur, per als quals es compta amb el Consorci d’Extinció d’Incendis i Salvament de la Regió de 
Múrcia i les brigades forestals de defensa contra incendis, d’intervenció ràpida, helitransportades, i d’auxili immediat, a més dels voluntaris de Protecció Civil.

Així mateix, el pla compta amb tres helicòpters, dels quals dos estan de forma permanent a Alcantarilla i la Pila (Abarán), per afrontar situacions d'emergències, i el tercer, ubicat a la pedania de Lorca Zarcilla de Ramos, intervé durant el període de perill alt.

A més, s’identifica el grau de risc de cada època de l'any, en funció dels paràmetres marcats per la vulnerabilitat del territori i la probabilitat que registrin els incendis, elements que poden disminuir o agreujar la situació de risc. En aquest sentit, l'època de risc més elevat d’incendis forestals és la compresa entre l'1 de juny i el 30 de setembre; l'època de perill mitjà, de l'1 d'abril al 31 de maig, més el mes d’octubre, mentre que el període de menys perill va de l’1 de novembre al 31 de març.

\section{Ordenances municipals ambientals ${ }^{2}$}

\subsection{Sorolls i vibracions}

El BORM, de 9 de març de 2011, publica l’Ordenança, de 10 de setembre de 2009, de l'Ajuntament de La Unión sobre protecció del medi ambient contra l'emissió de sorolls i vibracions.

L’ordenança s’estructura en nou títols. El títol I conté les normes generals (art. de l'1al 4), el títol II introdueix definicions (art. 5) i les normes sobre mesurament i valoració de sorolls (art. 6), així com les exigències d’homologació dels aparells de mesurament (art. 7). El títol III (art. del 8 a l’11) regula els nivells de pertorbació per sorolls, i el títol IV (art. 12) les condicions acústiques de les edificacions. El títol V (art. del 13al 19) regula les emissions de sorolls procedents de vehicles de motor. El títol VI (art. del 20 al 40) preveu els sorolls procedents de discoteques, bars amb música, superfícies comercials i altres activitats així com els procedents de treballs a la via pública, treballs d’edificació, les activitats pertorbadores del descans aliè en l'interior dels habitatges i, finalment, de sistemes d'avís acústic. El títol VII regula la contaminació procedent de vibracions (art. 41 i 42) i les zones d’especial protecció ambiental (art. del 43al 49). El títol VIII, “règim

\footnotetext{
${ }^{2}$ La referència completa a les ordenances ambientals dels municipis de la Regió de Múrcia és al web $<\underline{\text { http://www.ciss.es/Ordenanzasmunicipales/index.html }>\text {. }}$
} 
jurídic”, regula les actuacions d’inspecció dels funcionaris municipals (art. del 50 al 56) i, finalment, el títol IX les infraccions i sancions. L’ordenança es completa amb quatre disposicions transitòries, una disposició final —entrada en vigor- i vuit annexos.

Aquesta àmplia normativa té unes quantes deficiències que posen de manifest una tècnica normativa defectuosa i, més enllà, el descuit impropi de l’Administració pública. Així, el transcurs de més d'un any mig des que es va aprovar fins que s’ha publicat fa que l'ordenança no s'adeqüi a la legislació ambiental aprovada en l'interval per l’Administració de la CARM, assenyaladament la Llei 4/2009, de 14 de maig, de protecció ambiental integrada. Més enllà, els errors de numeració dels títols (hi ha dos títols VI i dos VII) i els de redacció (ad ex. art. 14. 1: "Se prohíbe forzar las marchas de los vehículos a motor produciendo ruidos molestos como aceleraciones, forzar el motor en pendientes, etc.”) posen de manifest les deficiències esmentades.

\subsection{Infraestructures radioelèctriques}

El BORM, de 4 de març de 2011, publica l'Ordenança, de 10 de setembre de 2009, de l’Ajuntament de La Unión reguladora de la instal-lació i del funcionament d’infraestructures radioelèctriques.

La justificació d’aquesta norma municipal es troba en el gran desenvolupament i implantació de les noves tecnologies de la comunicació, en concret, de la telefonia mòbil, que té com a conseqüència la proliferació de les instal·lacions necessàries perquè funcionin aquests mitjans de comunicació amb un fort impacte sobre el paisatge urbà i natural i, més enllà, sobre la qualitat de vida dels ciutadans. D’aquesta manera, l’ordenança regula les condicions aplicables a la localització, instal·lació i desenvolupament de les infraestructures radioelèctriques de comunicació.

Sens dubte, un dels aspectes que més preocupen els ciutadans amb relació a aquest tipus d'instal-lacions és la protecció enfront dels possibles efectes nocius per a la salut de les persones que poden derivar de l'exposició a camps electromagnètics (CEM). Aquesta ordenança municipal estableix una sèrie de cauteles en aquest sentit, tant mitjançant la reglamentació de les condicions urbanístiques, de protecció ambiental i de seguretat que han de complir aquest tipus d'instal-lacions, com el sotmetiment a llicència de l'activitat inherent. 
L'ordenança s'estructura en set capítols. El primer estableix l'objecte i l'àmbit d’aplicació (art. 1 i 2). En concret, l’objectiu és regular les condicions urbanístiques i mediambientals a què s’han de sotmetre la ubicació, la instal·lació i el funcionament d'aquestes infraestructures al municipi “a fin de que su implantación se realice con todas las garantías urbanísticas, medioambientales y de seguridad y salubridad para los ciudadanos y se produzca la menor ocupación y el mínimo impacto visual y medioambiental en el entorno” (art. 1). El capítol II (art. del 3 al 7) conté les regles sobre planificació i desenvolupament, en concret, exigeix aprovar un pla d’implantació com a condició imprescindible perquè el municipi atorgui les llicències pertinents (art. 6). El capítol III (art. 8 i 9) regula les limitacions de la instal-lació d’aquestes infraestructures i les condicions de protecció ambiental i de seguretat. Amb caràcter general, les instal-lacions radioelèctriques de telecomunicacions han d' “utilizar la solución constructiva disponible en el mercado que, con las menores dimensiones, reduzca al máximo el impacto visual y ambiental" i han de "resultar compatibles con el entorno e integrarse arquitectónicamente de forma adecuada” (art. 9. 1). El capítol IV (art. 10-13) estableix el règim jurídic de les llicències i el V (art. del 14 al 17) les regles de conservació i manteniment de les instal-lacions. El capítol VI introdueix el règim de protecció de la legalitat i sancionador de les infraccions en aquest àmbit, i el VII el règim fiscal.

L’ordenança conté, així mateix, una disposició addicional, que preveu crear un registre especial en el qual s'han d'inscriure totes les instal-lacions radioelèctriques que hagin obtingut la llicència municipal corresponent, i tres de transitòries sobre les instal-lacions existents, les sol-licituds presentades i l'adaptació a canvis tecnològics. Una disposició final — entrada en vigor- i un annex, que conté les definicions de conceptes utilitzats, en completen el contingut.

\subsection{Contaminació lumínica}

El BORM, de 17 de març de 2011, publica l’Ordenança municipal de regulació de l’enllumenat exterior per a la prevenció de la contaminació lumínica i la protecció del medi nocturn de l’Ajuntament de La Unión.

L’Ordenança recorda, en l'exposició de motius, que la contaminació lumínica constitueix un malbaratament d'energia que produeix greus perjudicis de tipus 
econòmic, afecta negativament l'atmosfera, perjudica la biodiversitat, pertorba la ciutadania, provoca inseguretat vial i impedeix la contemplació i gaudi del patrimoni cultural i científic, que és el cel estelat. D’aquesta manera, defineix la contaminació lumínica com "la emisión de flujo luminoso de fuentes artificiales nocturnas en intensidades, direcciones, rangos espectrales y/u horarios innecesarios para la realización de las actividades previstas en la zona donde esté instaladas las luces” (art. 1.1). Els objectius que persegueix són: promoure l'eficiència energètica i l'estalvi d'energia, protegir el medi ambient nocturn, eliminar molèsties i perjudicis a la ciutadania, augmentar la seguretat viària i, entre altres, permetre el gaudi i l'observació del cel nocturn (art . 2). El capítol II (art. del 5 al 9) estableix les característiques i el funcionament de les instal-lacions d'enllumenat exterior referides a les lluminàries (art. 5), flux lluminós (art. 6), il·luminació ornamental, publicitària i paisatge miner (art. 7), canons de llum i làser (art. 8: "Dado que el uso de cañones de luz convencional y láser dirigidos hacia el cielo representa una actitud contraria a los principios expresados en esta Ordenanza, quedan prohibidos en todo el término municipal de La Unión”). Finalment, l'article 9 estableix l'horari a partir del qual s'ha de reduirla intensitat lumínica.

El capítol III (art. del 10 al 16) regula la intervenció de l’Ajuntament tant pel que fa al disseny de les instal-lacions d'enllumenat exterior dels nous projectes com del manteniment de les existents i substitució de les preexistents. En concret, "el Ayuntamiento de La Unión sustituirá los alumbrados existentes por otros que se adecuen a la presente Ordenanza en el plazo máximo de 9 años” (art. 11. 1). Finalment, l’ordenança conté un últim capítol, el IV, relatiu al règim sancionador, que inclou l’obligació de l’infractor de reparar la causa origen de la infracció (art. 19.3).

\subsection{Agricultura tradicional}

El BORM, de 23 d'abril de 2010, publica l'Ordenança, de 5 de febrer de 2010, de l’Ajuntament de Cieza, reguladora del règim d’ús i protecció de les sèquies i l’horta.

L'ordenança constata que actualment les activitats agràries tradicionals es troben en una situació difícil, com a conseqüència de les transformacions socials i econòmiques que es dirigeixen cap a tasques relacionades amb el sector industrial, agrari, terciari i de serveis. Aquesta norma local pretén regular i recollir usos i costums de Cieza, municipi 
amb reconeguda activitat agrícola i usos agraris del sòl, i els regs immemorials que es realitzen des de les sèquies de la seva horta que cal protegir per vetllar per la tradició rural que, fins a la industrialització, va caracteritzar els usos i costums d'aquesta localitat.

El substrat consuetudinari d'aquesta regulació determina la forta presència d'usuaris, de manera que “cualquier propuesta de modificación, derogación o suspensión que afecte a esta Ordenanza, requerirá audiencia previa de la Junta Central de Usuarios de la huerta de riego de las acequias mayores” art. 2). En efecte, l’ordenança pretén “positivar” el cos consuetudinari de normes de la Vega Norte del riu Segura per resoldre millor els conflictes, tan freqüents en la realitat, que se susciten com a conseqüència de l'exercici de l'agricultura.

Així,l’article 4 delimita les infraestructures que són propietat de la comunitat de regants així com altres drets de pas i servitud sobre les finques confrontants (llits, talussos, dics, escorredors i cintres). Regula els camins de servei (art. 5) i el dret d'accés de la comunitat a través de finques alienes (art. 6), així com les canonades de transport i elevació (art. 7) i les zones de protecció (art. 9).

Inclou l'article 8 sobre prohibició d’abocaments, que, de forma addicional a la legislació estatal i autonòmica aplicable, pot suposar una via de protecció complementària de l'aigua de reg.

En definitiva, una ordenança local amb origen en normes consuetudinàries que pretén salvar les restes de l'agricultura tradicional en una societat que ha sofert un fort procés d’urbanització i industrialització.

\section{Algunes reflexions finals sobre el període objecte de crònica}

L'absència de normativa ambiental rellevant durant el període objecte de crònica, reflex d’una veritable atonia de les polítiques ambientals en la Regió de Múrcia, contrasta amb els ambiciosos objectius ambientals que per a aquesta lànguida VII legislatura es van proclamar en el discurs d'investidura del president regional. L'incompliment de bona part del programa de govern en aquest àmbit deixa pendents actuacions anunciades, com l'aprovació del Pla Integral de Protecció del Mar Menor, que havia de preveure un conjunt de mesures mediambientals relatives al paisatge, al foment de la sostenibilitat del transport, en ús d’energies alternatives i l’ampliació de les platges naturals, així com 
programes de recuperació d'encanyissades i d'ús sostenible d'aquest emblemàtic espai marí.

En les “entrades” del compte de resultats s'ha de consignar, igualment, la manca de l'anunciada configuració d'una veritable xarxa d'espais naturals amb especial valor ambiental, que preservi les peculiaritats de la flora i fauna i la singularitat dels ecosistemes regionals. Finalment, no se sap res de l'anomenada Ciutat del Medi Ambient, que, segons el president de la CARM, inclouria el Centre Regional d’Interpretació de la Natura, el Centre de Recursos Filogenètics d'Espècies Silvestres de la Regió de Múrcia, l’Escola Regional de Caça i Pesca, el Centre de Lluita contra Incendis i el Centre de la Biodiversitat.

L’aposta per reforçar la protecció del medi ambient i la natura a la Comunitat Autònoma de la Regió de Múrcia, en un context econòmic de crisi greu, queda postergada novament. Confiem, com fins ara, que les pròximes cròniques puguin donar compte d’avanços més substancials de política i legislació ambiental a aquesta comunitat autònoma. 